\title{
A Review on Present Scenario of COVID-19 in Bangladesh
}

\section{Mohammad Rejaur Rahman ${ }^{1}$, Emran Hossain Sajib², Ishtiak Malique Chowdhury ${ }^{1}$, Anik Banik $^{2}$, Rahul Bhattacharya ${ }^{3}$, Hasan Ahmed ${ }^{4}$}

\section{Affiliation:}

1. Department of Molecular Biology \& Genetic Engineering, Sylhet Agricultural University, Sylhet-3100, Bangladesh.

2. Faculty of Biotechnology \& Genetic Engineering, Sylhet Agricultural University, Sylhet3100, Bangladesh.

3. Department of Basic Science and Language, Sylhet Agricultural University, Sylhet-3100, Bangladesh

4. Department of Forestry and Environmental Science, Shahjalal University of Science and Technology, Sylhet 3114, Bangladesh.

\section{Corresponding Author:}

Mohammad Rejaur Rahman, Assistant Professor, Department of Molecular Biology and Genetic Engineering, Sylhet Agricultural University, Sylhet-3100, Bangladesh.

Email:rejaur.mge@sau.ac.bd

\begin{abstract}
The COVID-19 pandemic caused by SARS-CoV-2 has been showing a speedy growth in the number of infected patients with a remarkable mortality rate, thus it has become a worldwide public health concern. From March 8, 2020, the disease was confirmed to start spreading in Bangladesh. Since then, people got infected so exponentially that the country positions at the list of top infected countries in the world. Therefore, the objective of this comprehensive review was representing overall scenario of COVID-19 in different sectors of Bangladesh, particularly prioritizing the health sector. Up to 14 September 2020, 339,332 confirmed cases and 4,759 deaths were reported. An alarming fact is that while the global mutation rate of coronavirus is $7.23 \%$ in average, the rate is $12.6 \%$ in Bangladesh. Although the government ruled preventive strategies such as nationwide lockdown, social distancing, contact monitoring, quarantine and isolation, it was difficult to implement those due to lack of public awareness, inappropriate attitudes and so on. Moreover, the overburdened healthcare system had a weak response at initial stage because of insufficient healthcare facilities. Consequently, this pandemic affected severely
\end{abstract}


almost all the important sectors of the country, specifically the economy, agriculture and health sectors. Hence, focusing on healthcare system as well as maintaining social distance and other essential precautions can limit the spread of infection and help to alleviate the severity of the pandemic.

Keywords: COVID-19, SARS-CoV-2, Pandemic situation, Bangladesh, Health sector, Biotechnology.

\section{Introduction}

The pandemic of coronavirus disease in 2019 (known as COVID-19) is considered as a potential threat to public health that gained global attention after the 2003 Severe Acute Respiratory Syndrome (SARS) [1], followed by 2012 Middle East Respiratory Syndrome (MERS) [2]. The chance of COVID-19 mortality is around 1\% and can kill infants, adults and elderly people with previous medical issues[3]. The clinical presentation varies from asymptomatic illness to severe respiratory failure and shock $[4,5,6]$. Symptoms include cough, fever and shortness of breath, and associated with headache, dyspnea,sore throat, myalgia,rhinorrhea, vomiting and nausea to different degrees[4, 5, 7]. Besides, patients also show neurological symptoms such as ataxia, convulsion [8] and some neurological signs such as hemorrhagic stroke, dizziness, psychiatric disturbances, acute necrotizing encephalopathy [9, 10].

On December 29, 2019, the virus emerged in the town of Wuhan, the capital of China's Hubei province [6, 7]. Since then, the infection spread to other regions of Asia, gradually reaching Europe, North America, South America, Africa and Oceania, rendering it a pandemic by March $2020[4 ; 11 ; 12]$. The International Committee of Taxonomy of Viruses (ICTV) classified the novel virus as severe acute respiratory syndrome coronavirus 2 (SARS-CoV-2) [13, 14].On January 30, the World Health Organization (WHO) categorized the 2019-nCoV virus as the sixth Public Health Emergency of International Concern [15] and announced COVID-19 as a global epidemicon March 11, 2020.

The Institute of Epidemiology, Disease Control and Research (IEDCR), a research institute for monitoring COVID-19 in Bangladesh, first confirmed three reported cases of COVID-19 on 
March 8, 2020 [16]. Immediately, the government declared a nationwide lockdownon March 22 for 10 days (March 26 to April 04) [17]. Government of Bangladesh (GoB)has agreed to deploy armed forces since 24 March to promote social distance and disease prevention [18]. Until the end of March, infectionwas low but experienced a steep increase in April [19]. The disease growth percentage in Bangladesh became the highest in Asia on April 11 [20]. On June 13, the number of cases in Bangladesh outpaced the number of cases in China [21], whereas on September 11, the total death number became 4,668 surpassing the total death number of China [22]. Moreover, different districts of the country experienced variable scenario in terms of COVID-19 cases (Fig. 1 and Supplementary file 1).

Due to lockdown, the economy of Bangladesh has witnessed a drop of 6 \%age pointsfrom 2019 [23]. Resource constraints and inadequate medical facilities, insufficient testing facilities, personal protective equipment (PPE) and other protection measures also created barriers to combat Covid-19. Besides, public awareness and attitude, social distancing challenges, price hike and natural disasters made the crisis more difficult. A study by the Bangladesh Council of Scientific and Industrial Research (BCSIR) revealed that the mutation rate of Coronavirus in Bangladesh was $12.6 \%$, while the present global average is $7.23 \%$ [24].

\section{Materials and Methods}

The deadly COVID-19 is a recent outbreak, thus there is lack of availability of scientific publications from which we can collect information reflecting the ultimate impacts. For this reason, we chose numerous materials published by different research agencies, media outlets, newspapers, and policy experts in order to retrieve details information. Along with these resources, internet was used accurately as another source of information. We searched writing the Search items "SARS CoV2", "COVID-19", "Social Distancing", "public awareness", "Economical effects", "Agricultural effects", "Health Impact" using several combinations and permutations. This review was organized based on themes such as effects of COVID-19 on common people, COVID-19 impacts on economic sector, COVID-19 impacts on agricultural sector as well as situation of healthcare system in this pandemic.

\section{Results and Discussion}


In Bangladesh, COVID-19 is a humanitarian concern for public health. The crisis has triggered panic-buying, racism, and mistrust even in places where cases were not officially confirmed, or few cases were reported [25]. However, inconveniences and sufferings that appeared in Bangladesh during this pandemic situation are represented below:

\subsection{Mass Panic among People}

Though media portals transmitted substantial updates to mass individuals, it provoked negative consequences. For example, mass panic was highly visible even before announcing the first case from Bangladesh: breaking down of family relationships; patients and staff fleeing from a hospital after an immigrantwith flu-like symptoms was admitted [26]. Bangladesh also faced panic buying, terror, social stigma and hate during the lockdown.Mass panic is usually a consequence of misinformation, rumors, exaggeration and fake news circulated in different social media platforms. Owing to the fear of infection, family doctors, clinics and hospitals in residential and remote areas werealso shut down.

\subsection{Social Distancing Challenges}

Implementation of the WHO recommended social distancing is difficult in congested regions, especially in marginal communities [27]. In a heavily populated country like Bangladesh, strict social isolation is very difficult to enforce. There are many factors, including close proximity of residents, lack of healthcare concern, inadequate preparation,etc. Maintaining adequate distance is a major challenge for the residents sharing common kitchen, toilets and corridors [28]. Among the 49.5 million economically active workers, there are a large \% age of daily wage earners for whom the lockout is a curse. Besides, the garments industry, the second largest clothing supplier in 2017 with an earning of USD 29 billion, has been a significant obstacle against social distancing [29].

\subsection{Public Awareness and Attitude towards Pandemic}

Building Resources Across Communities (BRAC) survey (March 31 - April 05, 2020) revealed that around $40 \%$ of the respondents are unaware of avoiding infection [30]. Despite the lockdown, many of the people are disobeying the rules. Garment employees walked the streets for getting their unpaid wages [31]. Surprisingly, about 100,000 people attended a funeral of a 
famous Muslim cleric, rejecting calls from multiple places to retain physical distance and hygiene [32]. In print and online media, many other violations inside and outside the capital city are also reported, including excessive public meeting and roaming without excuse [33]. The risk is exacerbated by thousands of Bangladeshi returning from countries affected by COVID-19 [34].

\subsection{Rohingya refugees}

Bangladesh hosts about 1 million Myanmar Rohingya refugees, with approximately 626,500 residing inthe Kutupalong-Balukhali Expansion Site [35]. With more than 46,000 inhabitants per square kilometer, this location may be considered one of the densest settlements on earth [36]. The $84 \%$ refugees reported not having concern about water, sanitation and hygiene [37]. Every four out of ten children in the camps are afraid to die or lose a friend at COVID-19 [38]. On 9 April, GoB announced a lockdown in Cox's Bazar and directed prohibitions, but refugees are still arriving in Bangladesh [39]. Despite the preventive measures, first cases were detected in Rohingya camps on 14 May [40].

\subsection{Effects on Economic Sector}

Due to closing international borders, the scarcity of raw material sources and orders cancellationcreated a burden on Bangladesh. Readymade Garments Industry (RMG) got the attention because of the cancellation of nearly $\$ 3$ billion worth of work-orders that may affect approximately 4 million people directly involved in this industry [41].Banks in Bangladesh were suffering before the pandemic; the situation is becoming vulnerable day by day.Most pharmaceuticals companies also experienced a slump in sales, except for a few top ones. Drugs were not sold much, with the exception of those for hyperacidity, fever and cold [42]. Besides, the prices of basic commodities increased at a noticeable rate because of some unscrupulous traders who raised prices. According to the SANEM forecast, the poverty rate in Bangladesh will increase from $20.5 \%$ to $40.9 \%$ if Covid-19 leads to a $25 \%$ decrease in family income.Consequently, the successes over the past two decades in alleviating poverty can fizzle out [43].

\subsection{Effects on Agricultural Sector}


Access to agricultural products, materials, markets and advisory services was restricted during the lockdown, which greatly impacted farming.Agricultural processing and trade faced problems with impaired production activities by quarantine measures and low consumer demand, particularly due to limited hotel, restaurant and coffee shop operations [44]. Owing to logistical bottlenecks, farmers are still facing difficulties with having mineral fertilizers, veterinary supplies, and machinery spare parts. The country's fish and dairy farmers are now bearing their brunt. Crab, shrimp and fish farmers faced export restrictions, resulting in major economic losses. Exports from Bangladesh constitute more than $70 \%$ of crabs in the Chinese market. The export ban in China is a big setback for the crab industry [45]. Additionally, the prices of fruits, cattle and other agricultural products are also dropping. According to the Food and Agriculture Organization (FAO), the pandemic is causing major economic downturns linked to rising of hunger.It is necessary to avoid any distortions in the supply chain during harvest and to ensure food security during the second half of the year while planting spring crops in May and June.

\subsection{Health Sector}

The public healthcare system in Bangladesh is overburdened. The country spends less than five $\%$ of its Gross domestic product (GDP) on health [46]. China, for example, has a per capita health spending 10 times that of Bangladesh.Health professionals complained of not having sufficient PPE, proper training and other healthcare facilities that created difficulties in coping with the outbreak.

a) Quantity and Quality of COVID Test: According to IEDCR, on April 18, 2020, the rate of tests per million in Bangladesh was 124, holding the country among the worst performing nations, only above North Korea, Nigeria and Myanmar [47]. Then, with the increase of the number of tests, the number of positive cases increased quickly indicating that many of the patients were not tested and thus caused transmission excessively (Fig. 2). As number of positive cases raised, the death rate as well as the recovery rate showed upward trends (Fig. $3 \& 4$ ). As of September 14, a total of 1,742,696 tests were performed, reporting 339,332 confirmed cases, of which 243,155 completely recovered and 4,759 died. A total of 94 laboratories throughout the country are performing tests. RT-PCR laboratory test is basically available in these labs. Bangladesh faced a new challenge because, after retesting, false results have been revealed [48]. 
According to WHO, a retest is required for an accurate result. Dr.Meerjady, director of IEDCR, said, "We do a retest of full samples once a lab begins research. When the laboratory is stable, retesting is steadily decreased"[48]. Meanwhile, a group of Bangladeshi scientists, Dr. Bijon Kumar Sil and his fellow researchers developed a quick low cost $(\$ 3.25)$ test kit that uses the dot blot testing technique to scan for antibodies in the blood [49]. But some scholars including Dr. Kamrul Hasan Khan (a leading Bangladeshi physician) and Dr. Zahidur Rahman(a virologist) doubted the quality, since it had not been certified by international health organizations [49]. However, there are other tests available worldwide that may be employed in Bangladesh to mitigate these drawbacks:

- Genetic sequencing of the blood or respiratory tract swab samples is highly homologous with the known 2019-nCoV.

- As a key diagnostic instrument, Computed Chest Tomography can be used [50].

- Serology-based research can be used as a parameter of screening [51].

b) Safety Equipments and Treatment Facilities: Unavailability of PPE, masks and hand gloves was the major barrier to effective treatment faced by health service providers. About 4,000 health workers - doctors, nurses, pathologists and technicians - have been infected until June 23 [52]. The mortality rate for physicians was about $4 \%$ nationally; the highest in the world, where the overall mortality rate for physicians was $2.5 \%$ and experts said low-quality PPE as the primary factor [52].In Bangladesh, there are a total of 1,169 intensive care unit (ICU) beds, 432 of which are in government hospitals and 737 in private hospitals, compared to 170 million inhabitants [53]. There have 141,903 general hospital beds, means only 0.84 beds for every 1,000 individuals [53]. But the number of ICU beds in the hospitals should be in between 5\% and $12 \%[54,55]$. According to international norms, there should be at least five ICUs in a 100bed facility [56]. Besides, most of the ICU beds and ventilators are concentrated in the major urban centers, like the Dhaka city making it hard for rural communities to access.

c) Health Service Providers: Shortageof Doctors and Nurses is another trouble for Bangladesh. According to the Directorate General of Health Services, there are 93,358 MBBS and 9,569 BDS doctors in the region [57]. According to the new Health Bulletin issued by the Ministry of 
Health, the country has only six physicians, nurses and midwives for every 10,000 people [58]. Initially, private hospitals were reluctant to treat Covid-19 patients for the safety of other patients and a lack of training of medical personnel [59], thoughlater theystarted treating. Thus, the patients suffered due to a lack of treatment and the disease spread rapidly. However, the government agreed on April 27 to appoint 2,000 physicians and 6,000 nurses within a week and also 2,654 service providers, including lab attendants, helps, ward boys and conservancy workers for the next six months [60].

\section{d) Drugs}

There are no confirmed drugs, therapeutic sor vaccines available to treat COVID-19 effectively, though several research studies have been running worldwide since the first days. Initially, WHO concentrated on four potential therapies:an experimental compound named remdesivir; the chloroquine and hydroxychloroquine malaria drugs;a combination of lopinavir and ritonavir; and that same combination plus interferon-beta [61]. Next, Russiaapproved the anti-influenza vaccine, aviifavir [62], the European Medicines Agency (EMA) proposed remdesivirfor being approved [63], the UK experts claimed dexamethasone as a major breakthrough [64]. However, a major study including thousands of patients led by the University of Oxford showed hydroxychloroquine is ineffective [65] and studies involving animal models found that favipiravir had a very small effect [66].

While in Bangladesh, physicians have been prescribing multiple medications, including remdesivir and ivermectin [67]. After the UK news of dexamethasone,people in Bangladesh were in a mad rush to purchase the drug, which usuallybenefited the most severely illpatients requiring respiratory or ventilator support [68]. A Bangladeshi team headed by medical specialist Professor Tarek Alam reported pioneering findings of 100\% recovery (60 of 60 patients) within

4 days using ivermectin, antiprotozoal medication and doxycycline as a drug mixture [69].On 17 June, Bangladesh released these two medications for a clinical trial of 72 infected patients aged between 40 and 65 years with moderate illness for less than 7 days. The results have been good so far, but it still requires detailed research [70].

e) Convalescent Plasma The rapy (CPT): On 24 March 2020, the FDA approved physicians to use plasma obtained from recovered patients to treat seriously affected patients [71]. On May 6, 
at Evercare Hospital Dhakain Bangladesh, CPT was used to treat a COVID-19 patient for the first time [72]. Then, plasma therapy started to be used atan increased rate in the country. Dr. MA Khan, head of the Hematology Department, Dhaka Medical College and Hospital (DMCH) encouraged the use of CPT mentioning the therapy as harmless [73]. An online network launched by the GoBand a number of plasma banks also emerged across the country.

\section{f) Vaccine}

To launch the vaccine in Bangladesh, the ambitious efforts of Globe Biotech Ltd. attracted all because the company had successfully conducted a preliminary animal trial [74]. After successful two-phase animal trials in the pre-clinical stage, they were ready to initiate clinical trials of the homegrown vaccine [75]. Besides, Health Services Division Secretary Md Abdul Mannan mentioned if the vaccine is developed anywhere worldwide, it will urgently be brought. The government also invited the United States (US) to develop production plants for Covid-19 vaccines in Bangladesh [76]. Recently, Beximco Pharmaceuticals Limited claimed to import the vaccine produced by British pharmaceutical company AstraZeneca [77].

\subsection{Scope of Biotechnology in the Pandemic}

Biotechnology has been changing the world through advances in agriculture, medicine, pharmaceuticals, environment and others. While biotechnology is showing its blessings in this crisis in medical and pharmaceutical advances, the sector in Bangladesh needs more importance.Every year students of 25 universities in Bangladesh are being involved in several research activities worldwide after doing graduation in Biotechnology. For the first time in Bangladesh, Professor Dr. Samir Kumar Saha, SenjutiSaha and their team from the Child Health Research Foundation (CHRF) sequenced the genome of SARS CoV-2[78]. Later, many scientists unveiled the genome sequence of the virus, which showed similarity with the viruses of Saudi Arabia, Singapore, Russia, and Australia [78], that opened the milestone to study the virus to produce an effective vaccine against it.More than fifty graduates from the Biotechnology background who hold a graduate or post-graduate degree are serving as frontline fighters on a fully voluntary basis in the country by directly helping to set up laboratories and perform tests [79]. Though they are most eligible ones because of theoretical background and practical experience, they are not considered equally for Covid-19 testing, laboratory setup and any 
associated technical posts during recruitment. A few days ago, bioengineers from Stanford University developed a technique that suppressed $90 \%$ of coronaviruses, called prophylactic antiviral CRISPR in human cells, or PAC-MAN. It consists of an enzyme that destroys the Cas13 virus and a guide RNA strand that tells Cas13 to destroy unique nucleotide sequences in the Coronavirus genome [80]. Genetic Engineers from Bangladesh can come forward with this technique if adequate provisions are provided by the GoB.

\section{Conclusion}

The spread of the SARS CoV-2 has a significant impact on almost all crucial sectors of Bangladesh including economy, agriculture and especially the health sector. Inadequate public awareness and attitudes, and disobeying social distancing rules have added exceeding obstacles to combatthe pandemic. Though the GoB has taken several initiatives such as the lockdown strategy, different stimulus packages, Tk 50 billion granted for the agriculture sectoror the noticeable focus on health sector, it has been greatly difficult to fight COVID-19 by this developing country. The government, different organizations, experts like doctors, researchers, biotechnologists as well as the general people must function actively and simultaneously to overcome the devastating effects, while international support is remarkably important. Particularly, emphasizing on the health sector, by increasing treatment facilities, providing sufficient safety equipments, scaling up testing capacity, special focusing on appreciated drugs such as aviifavir, remdesivir, dexamethasone, importing vaccines immediately at low cost if developed anywhere in the world and investment in COVID-19 research sectors, is highly recommended to reduce the demolishing impacts of the pandemic as well as to mitigate the aftereffects in Bangladesh.

\section{References}

[1] World Health Organization (WHO). Summary of Probable SARS Cases with Onset of Illness from 1 November 2002 to 31 July 2003, https://www.who.int/csr/sars/country/table2004_04_21/en/; 2004. [Accessed ]

[2] World Health Organization (WHO). Middle East Respiratory Syndrome Coronavirus (MERSCoV), https://www.who.int/csr/don/2013_12_02/en/; 2013. [Accessed ] 
[3] Gates B. Responding to Covid-19-a once-in-a-century pandemic?. N. Engl. J. Med. 2020;382(18):1677-9.

[4] Chan JF, Yuan S, Kok KH, To KK, Chu H, Yang J, et al. A familial cluster of pneumonia associated with the 2019 novel coronavirus indicating person-to-person transmission: a study of a family cluster. The Lancet. 2020;395(10223):514-23.https://doi. org/10.1016/S0140-6736(20)30154-9.

[5] Chen N, Zhou M, Dong X, Qu J, Gong F, Han Y, et al. Epidemiological and clinical characteristics of 99 cases of 2019 novel coronavirus pneumonia in Wuhan, China : a descriptive study. Lancet. 2020;395(10223):507-13.

[6] Yang X, Yu Y, Xu J, Shu H, Liu H, Wu Y, et al. Clinical course and outcomes of critically ill patients with SARS-CoV-2 pneumonia in Wuhan, China: a single-centered, retrospective, observational study. The Lancet Respiratory Medicine. 2020; 395: 497506. https:// doi.org/10.1016/S0140-6736(20)30183-5.

[7] Zhu N, Zhang D, Wang W, Li X, Yang B, Song J, et al. A novel coronavirus from patients with pneumonia in China, 2019. N. Engl. J. Med. 2020;382:727-733. https://doi. org/10.1056/NEJMoa2001017.

[8] Baig AM. Neurological manifestations in COVID-19 caused by SARS-CoV-2. CNS NeurosciTher. 2020;26(5):499.doi: 10.1111/cns.13372.

[9] Li Y, Wang M, Zhou Y, Chang J, Xian Y, Mao L, et al. Acute cerebrovascular disease following COVID-19: a single center, retrospective, observational study.SSRN (Preprint). 2020. doi:10.2139/ssrn.3550025.

[10] Mao L, Jin H, Wang M, Hu Y, Chen S, He Q, et al. Neurological manifestations of hospitalized patients with covid-19 in Wuhan, China: a retrospective case series study. SSRN 3544840 [Preprint]. 2020.

[11] CSSE J. Coronavirus COVID-19 Global Cases by the Center for Systems Science and Engineering (CSSE) at Johns Hopkins University (JHU). 2020-03-15]. https://gisanddata. maps. arcgis. com/apps/opsdashboard/index. html\#/bda7594740fd40 299423467 b48e9ecf6. 2020.

[12] Rothe C, Schunk M, Sothmann P, Bretzel G, Froeschl G, Wallrauch C, et al. Transmission of 2019-nCoV infection from an asymptomatic contact in Germany. N. 
Engl. J. Med. $2020 \quad$ Mar 5;382(10):970-1. 382， 970-971. https://doi.org/10.1056/NEJMc2001468.

[13] Gorbalenya AE, Baker SC, Baric R, Groot RJ, Drosten C, Gulyaeva AA, et al. Severe acute respiratory syndrome-related coronavirus: The species and its viruses-a statement of the Coronavirus Study Group. bioRxiv. 2020. https://doi.org/ 10.1101/2020.02.07.937862 2020.02.07.937862.

[14] World Health Organization (WHO). Coronavirus Disease (COVID-2019) Situation Reports, https://www. who.int/emergencies/diseases/novel-coronavirus-2019/situationreports; 2020.[Accessed]

[15] World Health Organization (WHO). Statement on the Second Meeting of the International Health Regulations (2005) Emergency Committee Regarding the Outbreak of Novel Coronavirus (2019-nCoV), https://www.who.int/news/item/30-01-2020statement-on-the-second-meeting-of-the-international-health-regulations-(2005)emergency-committee-regarding- the-outbreak-of-novel-coronavirus-(2019-ncov);2020. [Accessed ]

[16] TBS Report. First coronavirus cases detected in Bangladesh. The Business Standard. 2020 March 08.

[17] Mamun S. "Coronavirus: Bangladesh declares public holiday from March 26 to April 4". Dhaka Tribune. 2020 March 23.

[18] Kamruzzaman M. Bangladesh to deploy troops to ensure social distancing. Anadolu Agency. 2020 March 23.

[19] Nabi MS and Shovon FR. 20-fold rise in Covid-19 cases in Bangladesh since April 1. Dhaka Tribune. 2020 April 14.

[20] Devulapalli S \&Dantewadia P. Mint Covid Tracker: India's corona trajectory has tapered this week but still remains steeper than Asian peers.Mint. 2020 April 11.

[21] Tribune Desk. Covid-19: Bangladesh surpasses China with 84,379 confirmed cases, deaths top 1,100. The Dhaka Tribune. 2020 June 13.

[22] UNB NEWS. Bangladesh's Coronavirus cases surge to 334,762. UNB. 2020 September 11.

[23] IMF Country Focus. Helping Bangladesh Recover from COVID-19. IMF News.2020 June 12. 
[24] Online Report. Mutation of coronavirus in Bangladesh faster than global rate: BCSIR study. The Daily Star. 2020 September 06.

[25] Shimizu K. 2019-nCoV, fake news, and racism. The lancet. 2020 Feb 29;395(10225):685-6. doi:https://doi.org/10.1016/S0140-6736(20)30357-3.

[26] Kamal RS. "Fear, hatred and stigmatization grip Bangladesh amid Covid- 19 outbreak." The Business Standard. 2020 March 26.

[27] Topader RA. COVID-19 threatens to cause a humanitarian crisis. Banglamirrornews. 2020 April 10.

[28] Ahmed N, Rony RJ, Zaman KT. Social Distancing Challenges for Marginal Communities during COVID-19 Pandemic in Bangladesh. J of Biomed Analytics. 2020 May 21;3(2):514.https://doi.org/10.30577/jba.v3i2.45

[29] BGMEA. "Bangladesh Garments Manufacturers and Exporters Association,"URL http://www.bgmea.com.bd/home/pages/TradeInformation; 2020. [Accessed ]

[30] BRAC. Bangladesh. Rapid Perception Survey On COVID19 Awareness and EconomicImpact, https://reliefweb.int/report/bangladesh/rapid-perception-survey-covid19-awareness-and-economic-impact-final-draft-may; 2020. [Accessed ]

[31] Reuters. Bangladesh Textile Workers Demand Wages in Protest. The Telegraph. 2020 April 27.

[32] Mahmud A \& Garcia J. 100,000 people gather for funeral in Bangladesh, defying coronavirus lockdown. CNN. 2020 April 19.

[33] Editorial Desk. Lockdown is a must to contain coronavirus. E-Prothom Alo. 2020 April 08.

[34] Monjur MR, Hassan MZ. Early phases of COVID-19 management in a low-income country: Bangladesh. Infect Control HospEpidemiol. 2020; 41(9):1116-1117. https://doi.org/10.1017/ice.2020.147.

[35] Cousins S. Rohingya threatened by infectious diseases. The Lancet Infect dis. 2018;18(6):609-10.https://doi.org/10.1016/s1473-3099(18)30304-9.

[36] UNHCR Mapping Unit. Rohingya Refugee Emergency at a Glance,https:/www.arcgis.com/apps/Cascade/index.html?appid=5fdca0f47fla46498002f 39894fcd26f; 2018. [Accessed March 9, 2020]. 
[37] Rahman MA, Shamol HH, Griffiths MD, Naher S, Hsan K. Factors associated with the practice of water, sanitation, and hygiene (WASH) among the Rohingya refugees in Bangladesh. J Water SanitHyg Dev. 2019;9(4):794-800. https://doi.org/10.2166/ washdev.2019.038.

[38] Taylor E. COVID-19: forty percent of rohingya refugee children in bangladesh are scared of dying or losing a loved one to the virus. Save the Children. 2020 June 25.

[39] Kuddus A and Uddin G. Rohingyas at sea for 2months, 32 die. Prothom Alo. 2020 April 17.

[40] TBS Report. Coronavirus cases detected in Cox's Bazar Rohingya camps. The Business Standard. 2020 May 14.

[41] Paul TC. COVID-19 and its impact on Bangladesh economy. The Financial Express. 2020 June 19.

[42] Noyon AU. A virus that even eats into pharma sector. TBS News. 2020 May 13.

[43] Ahmed HU. Economic ramifications of Covid-19 in Bangladesh. The Financial Express, 2020 May 07.

[44] Assaubayeva D and Bi Yi PW. Response to Covid-19 for sustainable agriculture transformation. The Financial Express. 2020 May 30.

[45] Roy R. Covid-19: Increasing economic resilience of the agriculture sector. The Business Stand ard.2020 May 05.

[46] Khatun F. Health sector cannot be improved only by resources. The Daily Star. 2020 May 11.

[47] MaswoodMH. Bangladesh among lowest testing countries. New Age.2020 Apr 19.

[48] Mamun S. Covid-19: False positive tests raise concerns. Dhaka Tribune. 2020 April 26.

[49] Islam A. Are Bangladesh's low-cost coronavirus test kits reliable? DW News. 2020 April 17.

[50] Ai T, Yang Z, Hou H, Zhan C, Chen C, Lv W, et al. Correlation of chest CT and RT-PCR testing in coronavirus disease 2019 (COVID-19) in China: a report of 1014 cases. Radiol. 2020;296:32-4. https://doi.org/10.1148/radiol.2020200642.

[51] Tang YW, Schmitz JE, Persing DH, Stratton CW. Laboratory diagnosis of COVID-19: current issues and challenges. J of clinical microbiol. 2020;58(6):e00512-20. DOI: 10.1128/JCM.00512-20 
[52] Corraya S. Doctors and health workers die from lack of quality protective equipment. Asia News.2020 June 23.

[53] Mamun A. Number of ICU beds insufficient to combat Covid-19 pandemic. The Daily DhakaTribune. 2020 March 21.

[54] Kennedy P, Prono vost P. Shepherding change: how the market, healthcare providers, and public policy can deliver quality care for the 21st century. Crit Care Med. 2006;34(3):1-6. doi: 10.1097/01.CCM.0000200041.68785.93.

[55] Mostafa N. Critical Care Medicine: Bangladesh Perspective. Adv J Emerg Med. 2018;2(3):e27.doi: 10.22114/AJEM.v0i0.79.

[56] Rungta N, Zirpe KG, Dixit SB, Mehta Y, Chaudhry D, Govil D, Mishra RC, Sharma J, Amin P, Rao BK, Khilnani GC. Indian society of critical care medicine experts committee consensus statement on ICU planning and designing, 2020. Indian J Crit Care Med. 2020;24(Suppl 1):43-60. doi:10.5005/jp-journals-10071-G23185.

[57] Debnath B \&Tajmim T. Doctors, nurses getting sick: Protective gear, curbs on nonessential services can save lives. The Business Standard/ Covid-19 in Bangladesh. 2020 April 16.

[58] Jahangir AR. Coronavirus: Bangladesh cannot afford losing doctors. UNB News. 2020 April 26.

[59] Tajmim T. Private hospitals unable, unwilling to treat coronavirus patients. The Business Standard. 2020 March 10.

[60] Opu MH. Govt to recruit 2,654 health service providers for 6 months. The Dhaka Tribune. 2020May 5.

[61] Kupferschmidt K\& Jon Cohen. WHO launches global megatrial of the four most promising coronavirus treatments. Science. 2020; https://www.utfa.org/content/wholaunches-global-megatrial-four-most-promising-coronavirus-treatments. [Accessed ]

[62] Sandberg J. Russians claim to have an effective treatment for the coronavirus, which hospitals will start using this month. Orthospinenews.2020 June 3.

[63] Euronews. Remdesivir becomes first COVID-19 drug put forward for use in the EU. Euronews.2020 June 25.

[64] Roberts M. Coronavirus: Dexamethasone proves first life-saving drug. BBC News. 2020 June 16. 
[65] Boseley S. Hydroxychloroquine does not cure Covid-19, say drug trial chiefs. The Guardian. 2020 June 5.

[66] FavipiravirAnd COVID-19. Favipiravir: Studies Involving Animal Models Shows Favipiravir Has Very Weak Effect On SARS-CoV-2 And Not Viable As An Effective Therapeutic. Thailand Medical News. 2020 Jun 23.

[67] Masum O. Bangladesh experts advise against using unproven drugs to treat COVID-19. bdnews24.com. 2020 June 01.

[68] TBS Report. Mad rush for coronavirus drug in Dhaka. The Business Standard. 2020 June 17.

[69] Singh N. Found effective drug combination to cure Covid-19 patients: Bangladeshi doctors. Hindustan Times. 2020 May 19.

[70] Press Trust of India. Bangladesh launches clinical trial of two-drug combination to treat Covid-19. Hindustan Times, 2020 June 17.

[71] NPR. FDA Expedites Treatment of Seriously Ill COVID-19 Patients with Experimental Plasma, https://www.npr.org/sections/coronavirus- live updates/2020/03/24/820939536/fda-expedites-treatment-of-seriously-ill-covid-19 patients-with-experimental-pla; 2020. [Accessed]

[72] Hossain MI. COVID-19: Bangladesh also exploring plasma therapy as a ray of hope. UNB NEWS. 2020 May 23.

[73] Masum O. Bangladesh experts advise against using unproven drugs to treat COVID-19. bdnews24.com. 2020 June 01.

[74] FE REPORT. Bangladeshi firm Globe Biotech in race to develop Covid-19 vaccine. The Financial Express. 2020 July 03.

[75] Hasan J. COVID vaccine: Globe Biotech ready to start clinical trial. The Financial Express.2020 September 12.

[76] Mirdha RU. US investors urged to set up Covid-19 vaccine plants in Bangladesh. The Daily Star. 2020 August 26.

[77] Staff Correspondent. Beximco to introduce AstraZeneca COVID-19 vaccine in BD. Daily Bangladesh. 2020 August 28.

[78] Tribune Desk. Bangladeshi father-daughter duo sequence coronavirus genome. Dhaka Tribune. 2020 May 20. 
[79] Staff Correspondent. Consider us equally for Covid-19 management jobs: biotech graduates. The Daily Star. 2020 June 15.

[80] ISAAA. CRISPR Technique 90\% Effective in Reducing SARS-CoV-2 Coronavirus, http://www.isaaa.org/kc/cropbiotechupdate/article/default.asp?ID=18157; 2020. [Accessed ] 


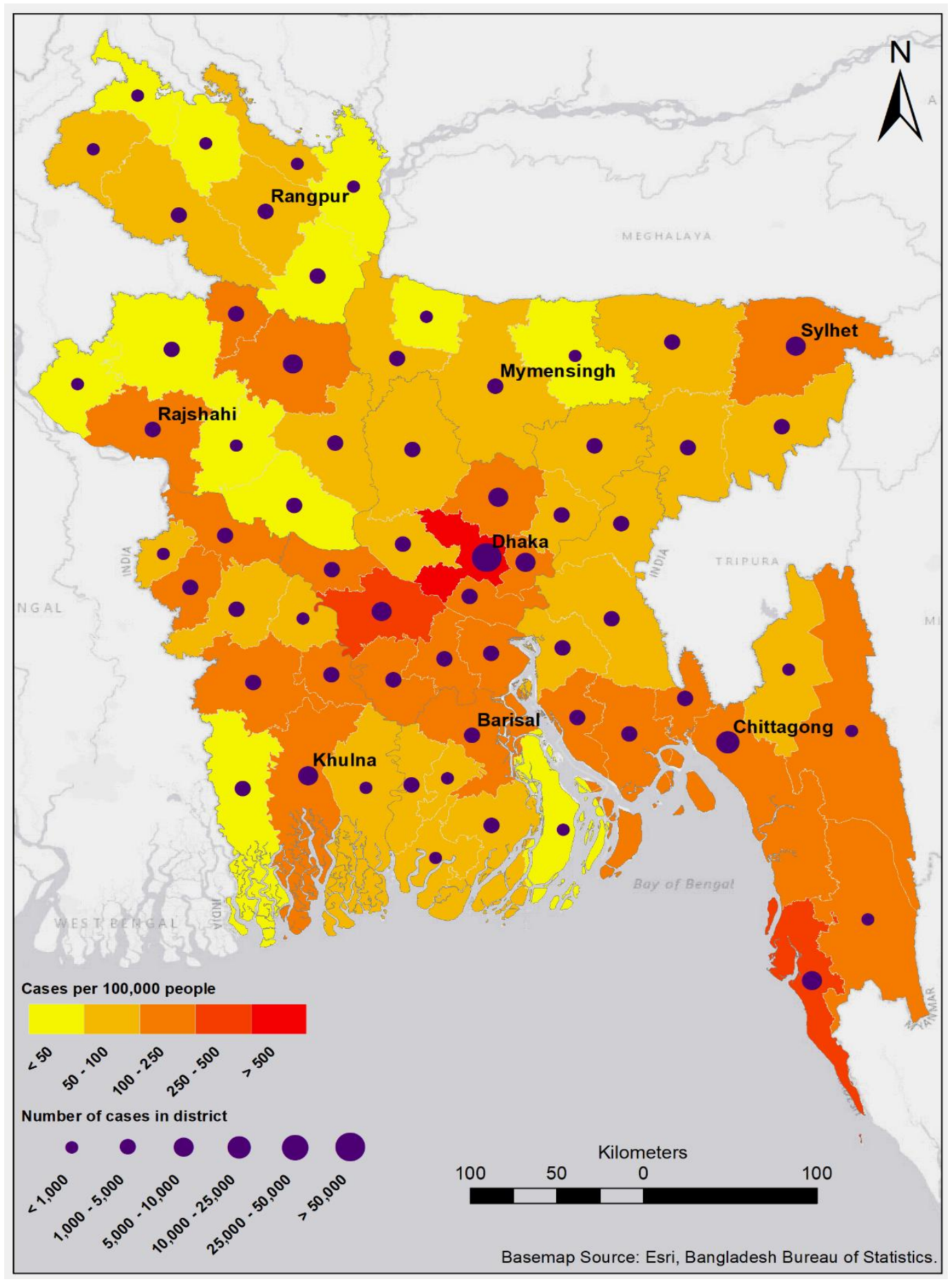

Figure 1: District wise scenario of COVID-19 confirmed cases in Bangladesh up to September 14 2020. The gradient of yellow to orange is representing the number of confirmed cases per 100,000 people in each district classified into five classes and the circle is representing the total confirmed cases per district. The data of confirmed cases was adopted from IEDCR 
(https://iedcr.gov.bd) and the data of population for each district was adopted from the Bangladesh Bureau of Statistics (BBS).

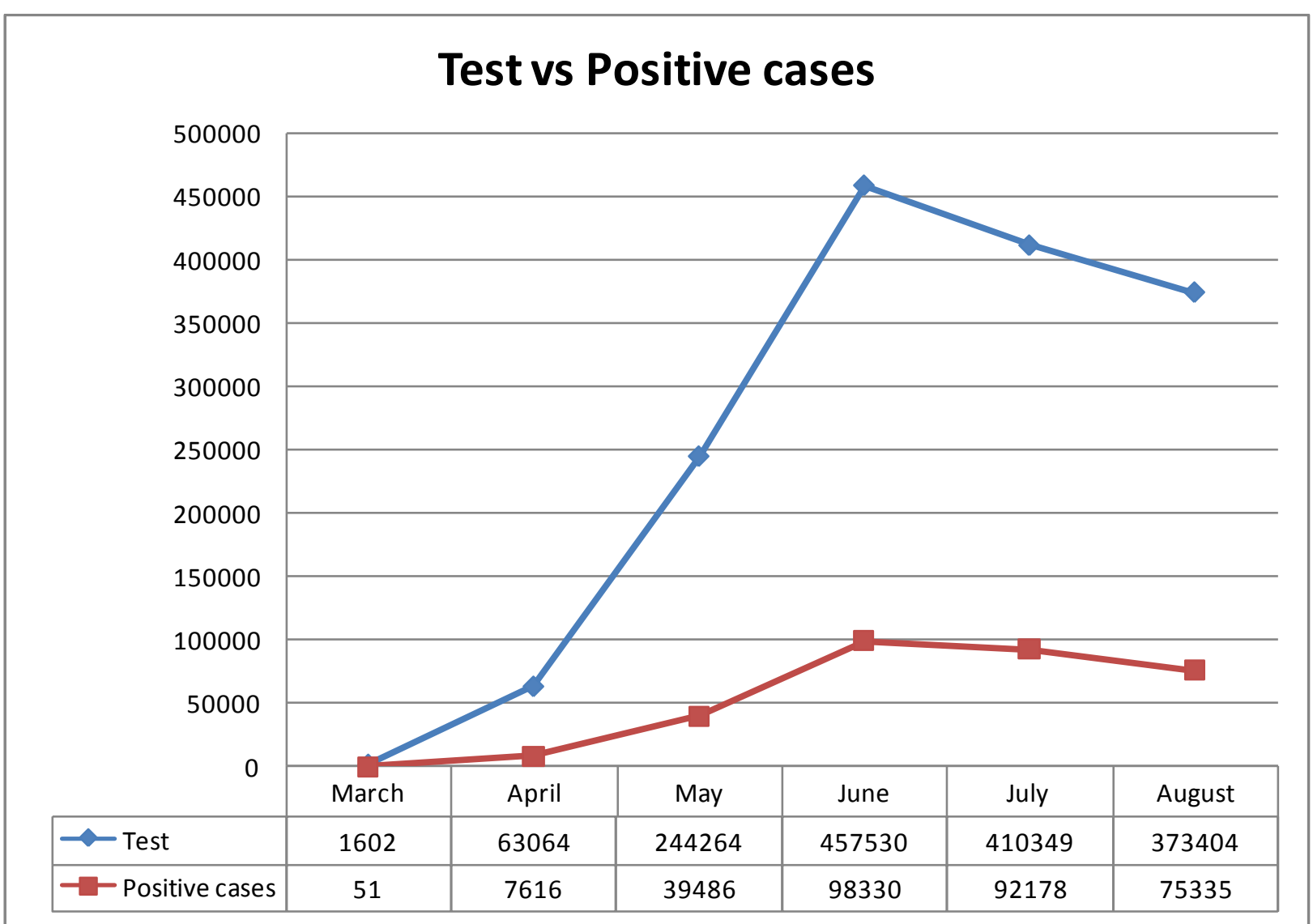

Figure 2: Monthly COVID-19 tests and positive cases in Bangladesh up to August (Available from https://iedcr.gov.bd). 


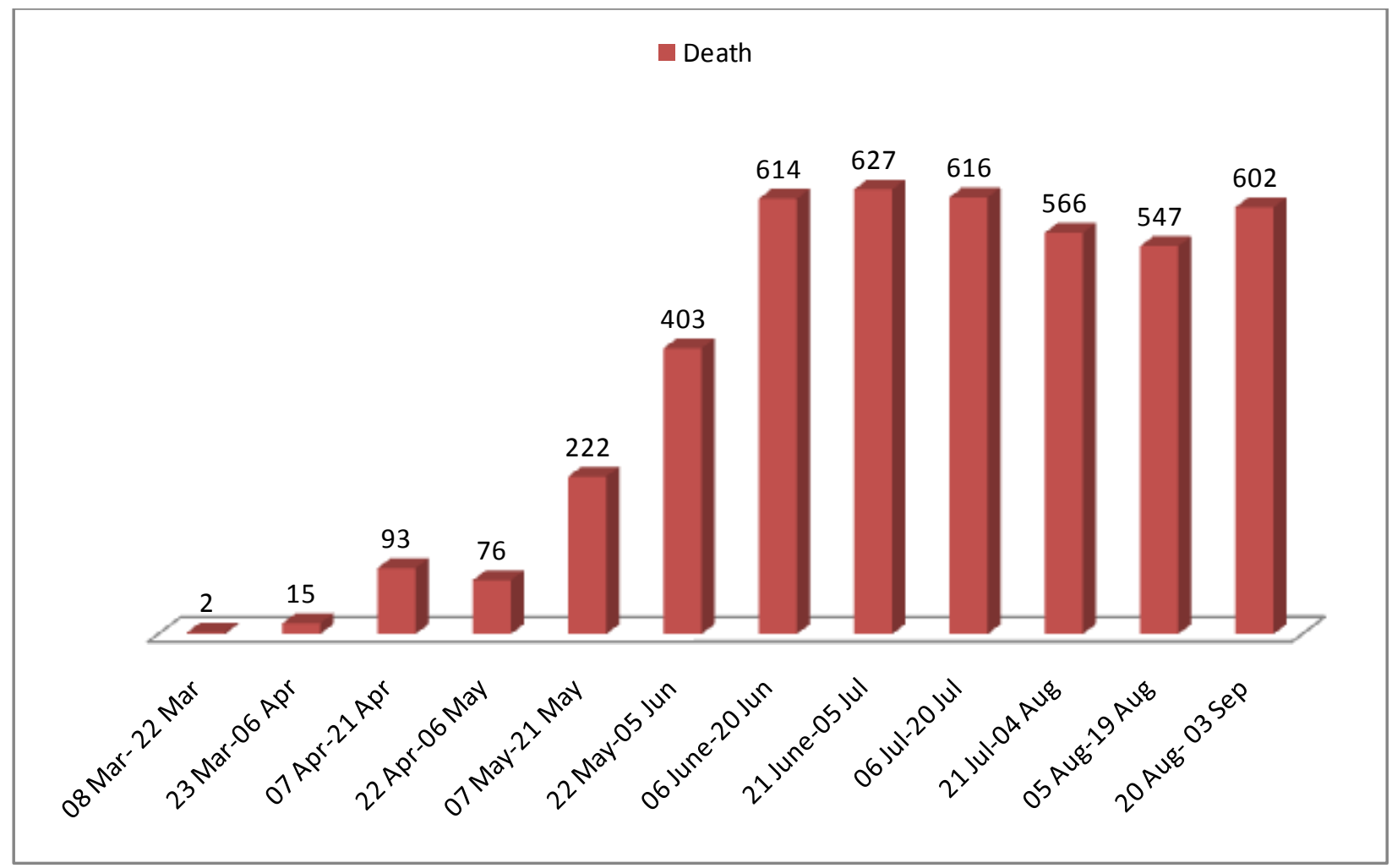

Figure 3: Distribution of number of deaths per 15 days (from 08 March to 03 September) by COVID-19 (Available from https://iedcr.gov.bd). 


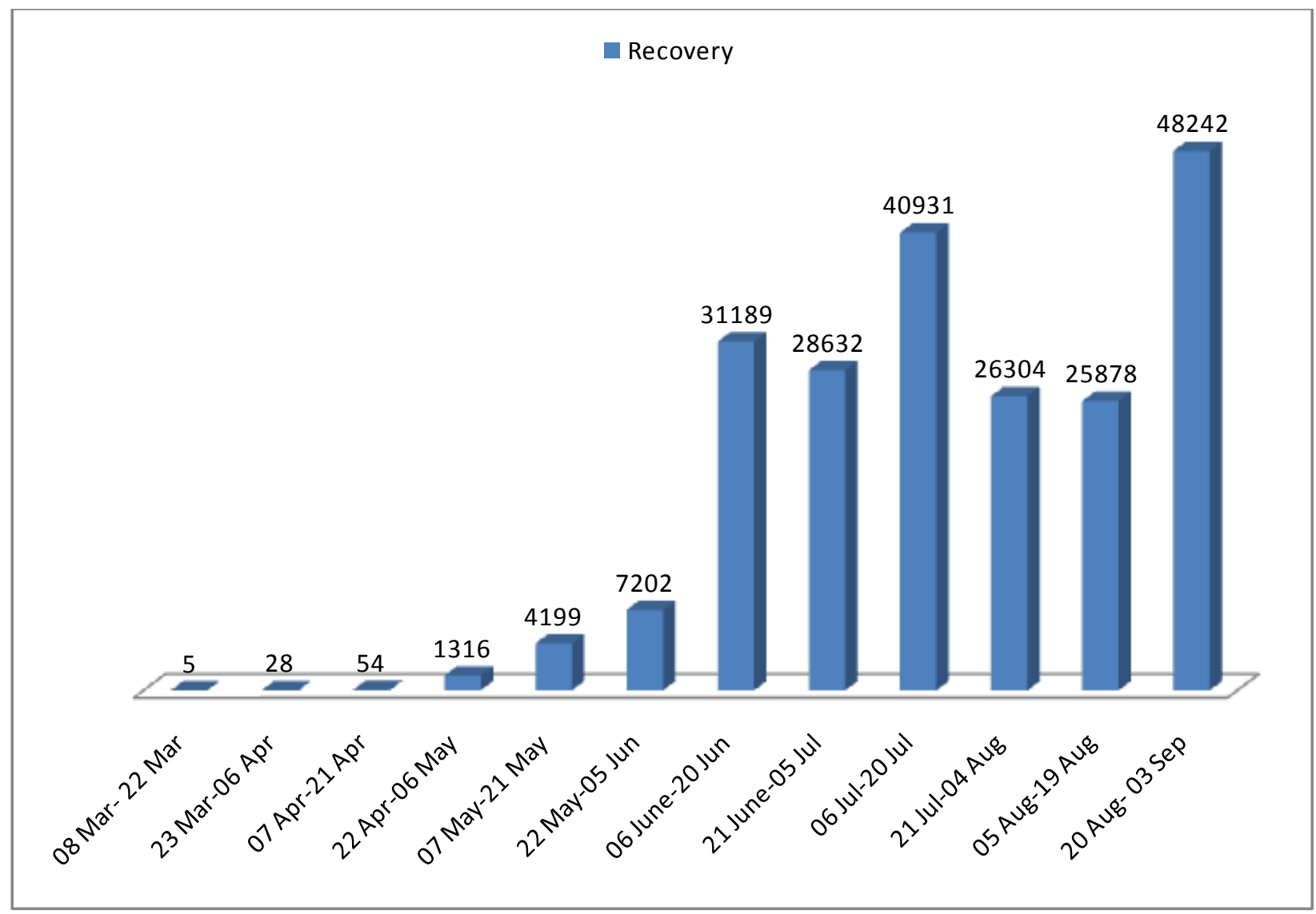

Figure 4: Distribution of number of recoveries per 15 days (from 08 March to 03 September) from COVID-19 (Available from https://iedcr.gov.bd).

Supplementary file 1: District wise COVID-19 confirmed cases in Bangladesh up to 14 September 2020 (Institute of Epidemiology, Disease Control and Research. Available from: https://iedcr. go v.bd.).

\begin{tabular}{|l|l|l|}
\hline Division & District & Confirmed cases \\
\hline \multirow{5}{*}{ Dhaka } & Dhaka & 88440 \\
\cline { 2 - 3 } & Faridpur & 6697 \\
\cline { 2 - 3 } & Gazipur & 5149 \\
\cline { 2 - 3 } & Gopalganj & 2432 \\
\cline { 2 - 3 } & Kishorgonj & 2601 \\
\cline { 2 - 3 } & Madaripur & 1409 \\
\hline
\end{tabular}




\begin{tabular}{|c|c|c|}
\hline & Manikganj & 1297 \\
\hline & Munshiganj & 3292 \\
\hline & Narayanganj & 6539 \\
\hline & Narsingdi & 2169 \\
\hline & Rajbari & 2807 \\
\hline & Shariatpur & 1584 \\
\hline & Tangail & 2822 \\
\hline Chattogram & Chattogram & 17590 \\
\hline & Bandarban & 708 \\
\hline & Brahmanbaria & 2368 \\
\hline & Chandpur & 2171 \\
\hline & Cox's Bazar & 4209 \\
\hline & Cumilla & 7008 \\
\hline & Feni & 1746 \\
\hline & Khagrachhari & 646 \\
\hline & Lakshmipur & 2033 \\
\hline & Noakhali & 4732 \\
\hline & Rangamati & 857 \\
\hline Sylhet & Sylhet & 6020 \\
\hline & Sunamganj & 2132 \\
\hline & Maulvibazar & 1562 \\
\hline & Habiganj & 1609 \\
\hline Rajshahi & Rajshahi & 4680 \\
\hline & Bogura & 6991 \\
\hline & Chapai Nawabganj & 728 \\
\hline & Joypurhat & 1007 \\
\hline & Naogaon & 1212 \\
\hline & Natore & 900 \\
\hline & Pabna & 1044 \\
\hline & Sirajganj & 2018 \\
\hline
\end{tabular}




\begin{tabular}{|c|c|c|}
\hline \multirow[t]{10}{*}{ Khulna } & Khulna & 5935 \\
\hline & Bagerhat & 929 \\
\hline & Chuadanga & 1298 \\
\hline & Jashore & 3512 \\
\hline & Jhenaidah & 1742 \\
\hline & Kushtia & 2917 \\
\hline & Magura & 846 \\
\hline & Meherpur & 558 \\
\hline & Narail & 1230 \\
\hline & Satkhira & 1059 \\
\hline \multirow[t]{6}{*}{ Barisal } & Barisal & 3272 \\
\hline & Barguna & 877 \\
\hline & Bhola & 684 \\
\hline & Jhalokati & 665 \\
\hline & Patuakhali & 1347 \\
\hline & Pirojpur & 1015 \\
\hline \multirow[t]{4}{*}{ Mymensingh } & Mymensingh & 3464 \\
\hline & Jamalpur & 1387 \\
\hline & Netrakona & 698 \\
\hline & Sherpur & 444 \\
\hline \multirow[t]{8}{*}{ Rangpur } & Rangpur & 2582 \\
\hline & Dinajpur & 3179 \\
\hline & Gaibandha & 1062 \\
\hline & Kurigram & 830 \\
\hline & Lalmonirhat & 769 \\
\hline & Nilphamari & 958 \\
\hline & Panchagarh & 537 \\
\hline & Thakurgaon & 992 \\
\hline
\end{tabular}

